that the majority of taxes are paid, that the markets in the bush are stocked with goods and clothing. The only drawback would seem to be the too prolonged absence of the Moshi migrants which is prejudicial to good farming in the Upper Volta. One of the remedies for this evil would be the relaxation of customs control which should not be an obstacle to the return of the Moshi labourers (the transfer of this labour to the Ivory Coast is not necessary because that country does not suffer from a shortage of workers; and the fear of the propagation of subversive political ideas seems to be unjustified at present). It seems therefore, that the French territories profit greatly from the migrations. They could profit even more by relaxing the customs duties, permitting international transportation, and facilitating transfer of money by post or through the banks. If this were done, migrants would return home more frequently and the repatriation of their funds would not represent a complete loss of currency. To control these journeys, a travel certificate would be indispensable and is indeed demanded by the migrants themselves.

- The effect of these migrations on Africa in general can be seen in the breaking down of the old barriers of warlike rivalries, especially between the forest and coast lands. The thousands of men who go down to the South each year and then return to the North may one day bring about a closer understanding between the Africa of the coast and that of the savannahs. The migrants themselves, Wangara, Gao, and Zabrama, may also bring into this Europeanized country something of the true African culture and ancient wisdom of old Ghana, Mali, or Songhay. Certainly this entirely new African élite, which has evolved in the course of these migrations, will play an essential role in the Africa of tomorrow.'

Dr. Rouch also reports that preparatory work for further research on the migrants into Ghana in 1958 has been carried out. The projected research includes studies sponsored and financed by the Ghana Government at the Bamboi and Yeji ferries, giving access to southern Ghana from the North, by a team which will include French African interpreters and will work for a period of a year. It is also hoped to secure funds for a similar investigation at the eastern entries across the lower Volta at Senchi bridge and Tefli ferry.

Meanwhile a team under Dr. Rouch's direction has also been investigating migration in the Ivory Coast. These studies, carried out from November 1956 to June I957, have included inquiries into factors affecting the stabilization of migrants in the Abidjan area, at Abengourou in Agni country, and at Gagnoa in Bete country. A pilot study on the character and intensity of migration has also been carried out at Buake in Baule country, Buake being a centre of concentration and dispersal of migrants coming from the North to seek employment in various parts of the Ivory Coast. This pilot study was carried out in NovemberJanuary 1956-7 and will afford a basis for a more prolonged sample survey at Buake. Further projected studies in the Ivory Coast include an investigation of cattle trading, for which Buake is an important transit, point, and an intensive study of selected migrant groups in the Ivory Coast.

\title{
Soviet Africanists' Co-ordinating Conference
}

THE following is a translation of extracts from a report by R. N. Ismagilova and L. D. Yablochkov in Sovietskaia Etnografia, 1957, No. 3, of a conference which took place on 26 February 1957 at the Ethnographic Institute of the Academy of Sciences of the U.S.S.R. devoted to the co-ordination of research work on Africa in the various Institutes of the Academy. Members of the Institutes of Ethnography, Oriental Studies, Geography, World Economics, and International Affairs took part in the discussions; as well as Africanists from Moscow and Leningrad, scholars of other faculties and research institutions were present:

In a short introduction I. I. Potekhin (Institute of Ethnography) stressed the importance 
of the continued study in the U.S.S.R. of the history, economics, ethnography, and geography of African countries. D. A. Olderogge (Institute of Ethnography) read a paper on social relations in the Western Sudan in the fifteenth to the nineteenth centuries, based on the study of indigenous chronicles. As a result of many years' research, D. A. Olderogge has concluded that in the Middle Ages feudal relationships were already dominant in the kingdoms of the Western Sudan, while the tribal structures remained mainly as anachronisms. G. E. Skorov (Institute of World Economics and International Relations) read a paper on the Algerian problem, and proved conclusively that the Algerian people-who have their own history and culture and had their own state organization in the past--have every right to demand self-determination for themselves. I. P. Yastrebova (Institute of World Economics and International Relations) dealt in her paper with the new economic and political features of the Union of South Africa. I. I. Potekhin gave a paper on the national problem in Africa and called on scholars to study with particular attention the ethnic composition of the population of African countries which have taken the road to the re-establishment of their independence.

The second part of the conference was devoted to the discussion of the joint plan for African research drawn up by the Institutes of the Academy of Sciences for 1957-60. In presenting the plans I. I. Potekhin pointed out that Soviet interest in African countries has greatly increased and that Africanists have a great obligation to the reading public. Prior to the October revolution only 294 books and pamphlets on Africa had been published in Russia. Starting with the first Russian book on Africa (Kokovtzev's The Description of the Archipelago and the Barbary Coast, 1786), up to 1917 , this meant an average of two books a year. Between 1917 and 1945 III books were published, i.e. four a year. Between 1946 and ${ }_{195} 6100$ books and pamphlets have appeared, i.e. ten a year. Of these 32 have been translations and 68 originals. But even this increase does not satisfy the demand which has arisen in the U.S.S.R. in connexion with the spectacular rise of the national liberation movement in African countries. Soviet scholars have to work out in the light of MarxismLeninism a number of problems of African history, economics, ethnography, philology, \&c.

I. I. Potekhin examined in detail each section of the plan and invited those present to make comments. The first section is devoted to the history of Africa before imperial partition. It includes: 'Studies in the history of the culture of the peoples of Western Sudan', 'The Arab colonization of East Africa ', 'The social structure of Madagascar in the I9th century', 'Monomotapa', \&c. A bibliography of Arab sources on the history of medieval Africa is being planned. Research workers at the Institute of Ethnography in Leningrad, under the direction of D. A. Olderogge, have already done preliminary work on the selection of sources. It is intended to publish four volumes by 1960 of so-6o pages each. I. 1. Potekhin went on to say that up till now far too little had been done in the Soviet Union on African history prior to colonization; but the study of this period of history is of enormous interest and great political significance. As they throw off the colonial yoke, the peoples of Africa show an ever-increasing interest in their past. African scholars, with the help of the progressive scholars of the world, unmask the lies of imperialist propaganda which maintains that African countries have no history. It is the duty of Marxist historians to take a hand in the re-establishment of historical truth.

The second section is called: "The imperialist partition and re-partition of Africa'. It includes five papers: 'The Berlin Conference $x$ 884-85', 'Anglo-German rivalry in East Africa in the second half of the nineteenth century', 'French expansion in Western Sudan in the second half of the nineteenth century', 'Studies in the struggle of the Zulus and Xhosa against Anglo-Boer colonization', 'The struggle of the Mashona and Matabele against the colonization of Rhodesia'. The problem before the authors is extremely important and their task a responsible one. They have to show in what manner the seizure of 
territories takes place, the peoples' resistance to the inroads of the colonizers, and unmask the fables of bourgeois historians on the 'civilizing' role of the Europeans.

The third section is devoted to the study of the ethnic composition of Africa. This consists of: "The ethnic composition of the Belgian Congo', 'The population of the Federation of Rhodesia and Nyasaland', 'The settlements and dwellings of the Bantu', 'Studies in the ethnography of contemporary Ethiopia', 'The ethnic composition of Nigeria', 'The ethnic composition of Tanganyika', ' The ethnic composition of the Union of South Africa', and 'The ethnic composition of Angola and Mozambique'. In addition, the section of ethnic cartography is working out a detailed ethnographic map of Africa. This will probably be ready by the end of 1957 .

The fourth section is called "The economic situation and the national liberation movement in Africa after world war II'. This is the central section, and is planned to contain 20-35 studies. Some of the titles are as follows: "The economic development and the struggle of the peoples of Nigeria against imperialist domination after world war II ', 'The economic development and the struggle of the peoples of French West Africa against imperialist domination after world war II ', 'Liberia under the yoke of American monopolies', 'The national liberation movement in Uganda after world war II', 'The basic questions of the socio-economic development of the Belgian Congo after world war II', 'The peoples of Morocco, Algeria, and Tunis in their struggle for national independence', 'Social-economic changes and English colonial policy in British Africa', and 'The peasant problem in Egypt'. In the last few years, continued I. I. Potekhin, our readers have received a few works by Soviet historians and economists on contemporary Africa, such as the books of I. P. Yastrebova, G. E. Skorov, L. N. Vatolina, and others. They all suffer from one major shortcoming: the writers' whole attention is concentrated on external relations-the relations between the metropolitan country and the colonies. The problem is to study in all aspects the life of African peoples and the socio-economic processes taking place in African society. Our scholars have not done enough in that direction. We must first of all study the African village. We continue to talk of African peasants in general, though this 'peasantry in general ' no longer exists. The disintegration of peasant society is moving very fast. The African village is being torn apart by class contradictions. One can distinguish a very complicated intertwining of several distinct socio-economic relationships-feudal, capitalist, tribal. Perhaps the most difficult and important task of our economists is the study of these relationships. Work in this field, however, demands very thorough ethnographic knowledge. Therefore the co-operation of ethnographers and economists would be particularly fruitful; otherwise it will be very difficult to pick one's way through these complicated processes. Life also sets new problems before Soviet historians. First of all one must study thoroughly all the changes in the policy of colonial powers in Africa in the post-war years. Then it is essential to trace the birth and growth to maturity of new social forces in African countries holding their own against colonialism. There is not a single work which examines how the working class, the national bourgeoisie, and the national intelligentsia appeared on the political scene. Finally, economists and historians have to make a thorough study of the home and foreign policy of the national bourgeoisie which has come to power in Egypt, the Sudan, Morocco, Ghana, and other countries.

The fifth section contains two major historical works : ' The history of the Sudan republic' and 'The peoples of the Gold Coast in their struggle for independence'.

The sixth section consists of works on philology. We have so far done very little in this field. An African philologists' group was created only last year in the Ethnographic Institute in Leningrad and the systematic study of African languages and literature begun. Professor D. A. Olderogge has planned an extremely important theoretical work: 'An introduction to the study of African languages'. Two dictionaries-Swahili-Russian and 
Hausa-Russian-are being prepared, as well as a new edition of an Arab-Russian dictionary (Egyptian dialect). Of the other philological works which are planned one might mention 'Studies in the folklore and literature of the South African Bantu ', 'The origin and spread of Swahili', 'Studies in Swahili syntax', 'Studies in contemporary Egyptian literature ', \&c.

The last section is devoted to geography. The Institute of Geography of the Academy of Sciences of the U.S.S.R. has planned several works on Africa, including 'A physical geography of Algeria', 'Morocco, natural resources and economy', 'Egypt, natural resources and economy', 'The Federation of Rhodesia and Nyasaland'.

All the participants in the discussion welcomed the opportunities given by the conference, which was to provide the basis for the co-ordination of African studies in the Soviet Union.

M. B. Hornung (Institute of Geography) pointed out certain duplications in the plan, as, for example, the subjects chosen by the Oriental Institute- "The growth in importance of African raw materials in the system of contemporary imperialism ' and 'The part of African raw materials and population reserves in world war II '; the book 'The peoples of Morocco, Algeria, and Tunis in the struggle for national liberation ' (The Institute of World Economics and International Relations) in part duplicates the study 'The formation of independent Tunis' and 'The imperialist struggle in North Africa on the eve of and during world war II' (Oriental Institute). At any rate, if this is not actual duplication, it is at least an irrational use of resources, which is at present to be deprecated. This shortcoming of the over-all plan, in the opinion of M. B. Hornung, arises from the absence of one directing centre in African studies.

Members of the Leningrad section of the Institute of Ethnography, A. I. Sobchenko and E. N. Miachina, developed I. I. Potekhin's point on the outstanding importance of studying the ethnic composition of the various countries of the African continent.

In conclusion, the conference underlined the importance of close contact between all the research institutes of the Academy of Sciences working on Africa. The conference put on record the desirability of organizing an inter-disciplinary expedition to Africa, with the participation of geographers, philologists, ethnographers, economists, and historians. Scholars expressed the hope that their joint studies would fill the gaps in Soviet African studies and would give moral support to the peoples of Africa.

M. H.

\section{International African Seminars in Social Studies}

THE International African Institute, in collaboration with a number of centres of research and higher education in Africa, is to arrange a series of four international seminars in tropical Africa over the period 1958-6I. It has been generously granted funds for this purpose by the Ford Foundation. The seminars will consider and report on social research problems of significance for further social, economic, and educational development in Africa. They will also provide opportunities for research workers and other scholars holding posts in various parts of Africa to establish closer contact with each other and with their colleagues in Europe and America, and to exchange views on problems and methods of research. From fifteen to twenty persons will participate in each seminar.

It has been agreed that the successive seminars should be held in different regions, and offers for facilities for holding them have been made by the East African Institute of Social Research, Makerere College, Uganda; the Nigerian Institute of Social and Economic Research, University College, Ibadan, with the collaboration of I.F.A.N. and the University of Dakar; the University College of Rhodesia and Nyasaland, with the collaboration of the Rhodes-Livingstone Institute; and by the University of Lovanium, with the collaboration of I.R.S.A.C. 